\title{
CSNK1A1 wt Allele
}

National Cancer Institute

\section{Source}

National Cancer Institute. CSNK1A1 wt Allele. NCI Thesaurus. Code C51199.

Human CSNK1A1 wild-type allele is located within $5 q 32$ and is approximately $57 \mathrm{~kb}$ in length. This allele, which encodes casein kinase I isoform alpha protein, plays a role in the degradation of beta-catenin and is involved in the formation of gap junctions. 